\title{
TRIBUNAL TROUBLES: AN ANALYSIS OF THE POTENTIAL EFFECTS OF BILL 139 ON HOUSING AFFORDABILITY, AND THE TRANSPARENCY AND EFFICIENCY OF ONTARIO'S LAND USE PLANNING AND APPEAL SYSTEM
}

\author{
By \\ Kumail Raza \\ Bachelor of Environmental Studies (BES) \\ Honours Specialization in \\ Environmental Management \\ York University, 2017

\begin{abstract}
A Major Research Paper
Presented to Ryerson University

in partial fulfillment of the requirements for the degree of Master of Planning (MPI)

in Urban Development
\end{abstract}

Toronto, Ontario, Canada, 2019

(C) Kumail Raza 2019 
I hereby declare that I am the sole author of this MRP. This is a true copy of the MRP, including any required final revisions.

I authorize Ryerson University to lend this paper to other institutions or individuals for the purpose of scholarly research.

I further authorize Ryerson University to reproduce this MRP by photocopying or by other means, in total or in part, at the request of other institutions or individuals for the purpose of scholarly research.

I understand that my MRP may be made electronically available to the public. 


\title{
TRIBUNAL TROUBLES: AN ANALYSIS OF THE POTENTIAL EFFECTS OF BILL 139 ON HOUSING AFFORDABILITY, AND THE TRANSPARENCY AND EFFICIENCY OF ONTARIO'S LAND USE PLANNING AND APPEAL SYSTEM
}

\author{
(C) Kumail Raza 2019 \\ Master of Planning in Urban Development \\ Ryerson University
}

\begin{abstract}
This Major Research Paper (MRP) analyzes the potential effects of Bill 139 on housing affordability, and the transparency and efficiency of land use planning in the province of Ontario. Specifically, this MRP analyzes how changes to Ontario's Development and Land Use Appeals Process may impact the delivery of new housing supply to market, hence, impacting affordability. Additionally, this MRP evaluates changes in the appeals process in regards to increased transparency, an expected outcome of Bill 139. A qualitative analysis of the Bill 139 reforms finds that Ontario's land use planning and appeal systems require immediate assistance in regards to implementation, and further reform in terms of municipal autonomy, decision making power of the tribunal, and the nature of appeal hearings.
\end{abstract}




\section{ACKNOWLEDGEMENTS}

Thank you to Professor David Amborski, MCIP, RPP for the supervision of my MRP, and for never failing to tell a great story. Professor Amborski's feedback throughout this process was essential to the completion of this MRP.

I would also like to thank Patrick J. Devine of Devine Park LLP for agreeing to be my second reader. Mr. Devine's expertise in Ontario's municipal planning and appeal system greatly benefitted

Lastly, to my friends and colleagues at Ryerson's School of Urban and Regional Planning, it has been an absolute privilege to learn and grow with you over the course of these past two years. 
بِنْمِ اللَّهِ الرََّحْمَنِ الرََّحِيم

For my mother. 


\section{TABLE OF CONTENTS}

Chapter 1: Introduction............................................

Chapter 2: Literature Review...................................6

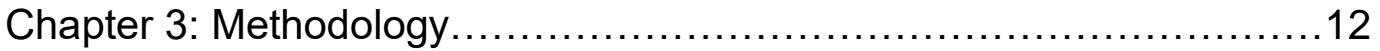

Chapter 4: Historical Context.....................................16

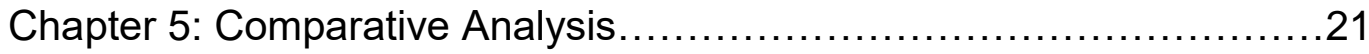

Chapter 6: Further Investigation................................. 33

Chapter 7: Final Discussion and Recommendations..................43

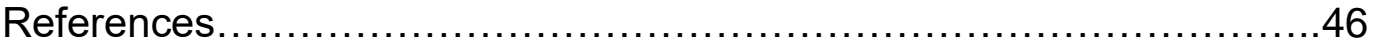




\section{CHAPTER 1: INTRODUCTION}

Housing affordability has reached crisis levels in Toronto. From 2010-2016, house prices increased by 40 per cent in the city as the average price of a home surpassed $\$ 700,000$ (Canadian Mortgage and Housing Corporation (CMHC), 2018). This rise in housing prices represents a serious economic threat to the city of Toronto as many young people are "seriously considering" leaving the city because they are unable to find a home that they can afford (Wilson, 2018). For a large economic hub such as the city of Toronto to thrive in an ever-shifting global economy, residents and workers must be able to afford to live close to where they live, work, and play.

A key factor in ensuring an adequate amount of housing stock gets to market is an efficient land use planning and appeal system. The Province of Ontario's decision to replace the Ontario Municipal Board (OMB) with the Local Planning Appeal Tribunal (LPAT), through the Building Better Communities and Conserving Watersheds Act, 2017, (Bill 139) has led to uncertainty within the housing market. Because the act has altered the development approval process, it will potentially affect 
when, where, and what type of housing gets built in the province (Residential and Civil Construction Alliance of Ontario (RCCAO, 2018)).

Under the previous model, the OMB had more power to enforce the test of "good planning". Once a planning decision was appealed to the $\mathrm{OMB}$, the Board would then apply the test of good planning through a de novo (from the beginning) hearing. At OMB hearings, applicants and appellants would have the opportunity to make the case as to how a proposal did or did not conform to the Official Plan and the Growth Plan, and was or was not consistent with the Provincial Policy Statement (PPS). The OMB was not limited to determining if the original decision was wrong or unreasonable, and its mandate was to determine if the proposed plan represented good planning and met all policy tests (Davies Howe, 2017).

In February of 2019, the LPAT backlog consisted of over 30,000 proposed residential units in over 100 rezoning applications (Landau, 2019). Toronto's Deputy Mayor Ana Bailão (2019) stated that "unnecessary delays in the planning appeals process affect everyone, from residents looking to rent or buy their first home to businesses looking for confidence that there is enough housing for a growing workforce. 
Clearing the backlog in a fair and efficient manner could be the best tool the Province has to quickly bring more housing supply to market."

With a new appeals system in place, Bench et al. (2018) believe that confusion will be "unavoidable" in the near future as development applicants, staff, city councillors, and the public begin to manoeuvre under two different sets of rules and appeals procedures; de novo hearings from pre-Bill 139 cases and appeals filed after Bill 139. Bench et al. (2018) further state that the new rules and timelines will lead to a significant amount of additional work, in the form of materials for consideration, for municipal councils and staff. Applicants will need to state how their proposal(s) conforms to the Growth Plan in addition to stating how the development proposal conforms to municipal Official Plans and zoning bylaws. A greater administrative burden such as this could potentially lead to higher processing fees from municipal planning departments (Bench et al., 2018) which could then be passed onto the consumer in the form of more expensive housing.

Additionally, there are political and market forces to consider when it comes to Ontario's land use appeal process. Shamez Virani (2018), President of Centrecourt Developments claimed that the builder's 
timeframe for development had doubled, that they were taking a more conservative approach to land acquisition, that they were targeting projects that allowed for more flexibility and have become open to entering new markets.

In terms of political influence, Joe Vaccaro (2018), CEO of the Ontario Home Builders' Association, has pointed out that the LPAT has increased the power of municipal councils. As such, if a politician who is vociferously anti-development were to be elected, that ward could easily become sterile in terms of development (Voccaro, 2018). This is in part due to the power of municipal councils to vote to approve or reject certain development applications such as Official Plan and Zoning By-Law amendments, and plans of subdivision. Additionally, if a municipal councillor represents a ward whose residents have anti-development sentiments, then that councillor may vote to reject applications solely for the purposes of his/her re-election.

Having the established the importance of, and link between affordable housing and an efficient land use planning appeals system, the Province of Ontario should look at the practices of other jurisdictions. The state of Oregon's planning system specifically is supposedly regarded as 
a global 'best practice' system because of its comprehensive integration of state and local planning practice and policy (Horne, 2014; Salsich Jr. and Trynieki, 2003). Additionally, some level of attention has been paid to its land use appeal body, the Land Use Board of Appeals (LUBA), and the effects it has had on development in the state of Oregon (Sullivan, 2000). By comparing the appeals systems of Oregon and Ontario with one another in terms of composition, adjudication methods, scope of review, the context in which they operate, and the involved stakeholders, we can: (1) determine if Oregon's system truly is more efficient, and (2) potentially prescribe legislative changes to Ontario's Land Use Planning Appeal system to increase the supply of housing thus alleviating Toronto's housing crisis.

Lastly, in addition to conducting a comparative analysis, this research will highlight some of the commentary surrounding the Bill 139 reforms and list potential consequences and legislative recommendations informed by academics, and experts in the land development industry. 


\section{CHAPTER 2: LITERATURE REVIEW}

Although research that compares land use appeal tribunals directly with one another is scarce, there is enough comparative literature as well as literature focusing on individual tribunals to shed light on key differences in composition, adjudicative methods, and the tribunals' scope. Mualam (2014) conducts a comparative analysis of three land use appeal tribunals in Oregon, Israel, and the United Kingdom. Research methods used by Mualam (2014) consist of jurisdictional legislative and policy scans, and reviews of other works focused on the planning systems of the aforementioned jurisdictions. Mualam (2014) also provides a detailed overview of the jurisdictions' structural planning context and describes the preliminary research as important to understanding the role and functions of the land use planning appeals systems and bodies.

Considering this MRP uses the state of Oregon as a case study, most of the initial academic research on tribunals and planning systems was focused on that State. Due to Oregon's notoriety in the global planning community, there were several sources that were available that discussed the state's planning system and appeals body. The state of Oregon was chosen because it is a considered a pioneer in formulating, 
adopting, and implementing jurisdiction wide growth management policies (Horne, 2014). As this paper analyzes potential issues with Ontario's general 'top-down' planning system, along with the appeals process, Oregon is an excellent jurisdiction to examine for getting a centralized planning system right.

Abbott et. al. (1994) conduct a twenty-year evaluation of Oregon's planning system and devote a section of the research to evaluating just the appeal system. This research also recognizes the need for an effective and robust land use planning appeal system to ensure transparency. While evaluations of a land use appeal system are important, reviewing the effects that an appeal system has on development can produce a direct correlation to housing affordability and patterns of growth within a state or city. Smith (2000) conducts an analysis of Oregon's Land Use Board of Appeals (LUBA) on the larger planning system, and urban development within different municipalities in the state of Oregon. Additionally, 1000 Friends of Oregon, a well-known non-for-profit entity that advocates for sustainable communities, has published a citizen's guide to Oregon's land use planning appeal system, and has also published an extensive amount of research related to smart growth in the 
state of Oregon, as well as general public participation in land use planning.

Barnett (2000) also conducts a comparative analysis of Oregon's planning system and the planning system of the Netherlands. Key aspects of Barnett's research speak to the balanced cohesion of Oregon's planning system and the emphasis of both a top-down and bottom-up approach. Lastly, Barnett (2000) lists the different growth management strategies used by municipalities in the state of Oregon to control development, and the roles of different state actors in applying and enforcing State planning law.

While the studies related to Oregon are dated, the article written on best practices for growth management by Horne (2014) sustains that Oregon's planning system has not undergone any significant changes since its inception and remains largely centralized.

A significant amount of attention has also been paid to the province of Ontario's planning system, with an emphasis on the appeals system and the Ontario Municipal Board. One such work is former OMB chair Bruce Krushelnicki's (2007) book, A Practical Guide to the OMB. 
Krushelnicki (2007) describes the history of land use appeals in Ontario and the political nature of land use appeals reform at different times in the province's history. Furthermore, Krushelnicki (2007) also speaks to the Board's functions and adjudicative methods. Although Bill 139 has changed the nature of appeal hearings to be less adversarial, Krushelnicki's (2007) work is an excellent guide for comparing the nature of hearings, the role of expert witnesses, and the role of the Tribunal before and after Bill 139.

Similarly, Howden (2017) details the history of the OMB in Ontario, in addition to describing the role of the appeals body in the greater context of Ontario's planning system. Howden (2017) speaks to the nature of the provincial-municipal relationship in Canada and provides case studies of municipalities contending with appeals when under pressure from development resulting from Provincial Planning Policy.

Moore's $(2009 ; 2013)$ research speaks to the relationship between the OMB and municipal politics in Toronto specifically. Considering OMB reform was heavily pushed for by residents and councillors in the city of Toronto, Moore's work is extremely relevant to the role elected officials had in a pre-Bill 139 environment. Moore also addresses some of the 
common critiques of the OMB, such as that it was too "developer friendly" with data related to OMB cases spanning the 2000s.

Around the time the Province of Ontario announced its intention to pass OMB reform, professional commentary about the reforms started being published by law firms, land development professionals, and academics in the city building community. Inger Squires (2017) of Toronto's Urban Strategies released commentary on Bill 139 that asked some key questions related to the Bill's intention and how it would be implemented. Squires (2017) also reflects on some of the initial reactions to Bill 139 such as that it was a charter for NIMBYs. Additionally, Davies Howe (2018) and WoodBull LLP (2017) provided excellent commentary on how Bill 139 has changed Ontario's land use planning appeal system. Both organizations apply a narrower focus that mostly touches on how the reforms will impact the development process in the province of Ontario. The commentary is more of a guide for developers and those interested in knowing how their appeal rights have been impacted by Bill 139 .

In terms of the OMB's impact on the physical fabric of Ontario's cities, Kumar (2005) deems it to be significant and lasting. In his study of the OMB's decision-making model, Kumar (2005) finds that the while the 
OMB certainly plays a consequential role in the development approvals process, it is not fully conducive for reviewing and adjudicating urban design. Kumar's (2005) study is relevant to this MRP as it affirms the importance of the OMB in terms of making decisions that lead to additional housing supply. Were it not for the OMB, applications that would bring thousands of new housing units to market would never have gotten approved. One such example is the 10,000-unit plan for Downsview Park that was approved in 2011 by the OMB (Fedio, 2011). As highlighted by Hilber and Vermuelen (2010), adding additional supply to market can alleviate housing unaffordability and that is much of what the OMB did on a consistent basis. 


\section{CHAPTER 3: METHODOLOGY}

The purpose of this research is to provide an analysis of the potential impacts of Bill 139, and Ontario's general planning system as it relates to land use appeals, on housing affordability in the province. The goal of this research is provide provincial policymakers with legislative and policy change recommendations that will help to alleviate Ontario's housing crisis.

This research will consist of a comparative analysis of Ontario's land use planning and appeal system to that of the state of Oregon's through a case study approach. The state of Oregon was chosen for the case study for two primary reasons. Firstly, the state of Oregon is a pioneer in formulating, adopting, and implementing jurisdiction wide growth management policies. As this paper analyzes potential issues with Ontario's general 'top-down' planning system, along with the appeals process, Oregon is an excellent jurisdiction to examine for getting a centralized planning system right.

Secondly, Oregon's LUBA and Ontario's LPAT serve a similar role in the sequence of their respective land use appeals processes. Both the 
LUBA and the LPAT are considered "first instance" appeals bodies. This means that both tribunals, in the majority of cases, are the first bodies to adjudicate a land use planning decision appeal (Mualam, 2014).

In the comparison of the two jurisdictions' appeals bodies, the points of focus will be the adjudicative method (the method of peaceful conflict resolution in which parties present arguments and evidence to a neutral third party for a decision, (Howard, 1969)), and their general composition in regards to membership. The tribunals' membership makeup and methods of adjudicating hearings, in regards to the nature of hearings, and the role of expert witnesses will be compared with literature related to effective adjudicative practice such as Barker (2013) and Hale (2004). The goal of this analysis is to gauge the level of transparency of both appeals systems as improved transparency is a key expected outcome of Bill 139. This stemmed from concerns raised by the public during the review (2016b) that hearings were too "court-like" and most people supported a less formal process. Whether less formality and more transparency are the same thing is a concept which this MRP will further explore. 
In addition to a conducting a case study of Oregon's land use planning and appeal system, the potential impacts of Bill 139 will be further investigated by highlighting and analyzing some of the key critiques of OMB reform as brought to light by Ontario's city building community. More specifically, all of the analysis of the critiques will be tied back to housing affordability.

One of the key issues brought up by critics of Bill 139 is the increase in development timelines. As part of the analysis, policy changes within Bill 139 that will increase development timelines will be listed. Once it has been established that Bill 139 will in fact increase development timelines, the effects of regulatory delay on housing affordability will be highlighted. This will be done by presenting research, such as Lai et al. (2016), and Dachis and Thivierge (2018), which analyzes the impacts of long development timelines on housing supply and housing affordability.

Furthermore, arguments related to the implications of NIMBYism, and issues with policy implementation will be listed. Similarly, academic literature which ties these concerns to impacts on housing affordability will be presented, in addition to concerns from Ontario's expert city building 
community by way of panel talks, published policy briefs, and professional blog posts. 


\section{CHAPTER 4: \\ HISTORICAL CONTEXT OF LAND USE PLANNING APPEALS IN ONTARIO}

The history of Ontario's land use planning appeal system dates back to 1906 with the establishment of the Ontario Railway and Municipal Board (ORMB) (The Ontario Railway and Municipal Board Act, 1906). Prior to the establishment of the ORMB, the Province of Ontario assigned a loosely formed commission during the 1880 s to contend with a political issue. The rapidly growing rail transportation system between and within municipalities had led to increased public complaints of noise and soot being scattered within towns (Howden, 2017 \& Krushelnicki, 2007). The commission was merely a number of men who travelled across Ontario to listen to complaints by citizens and report them back to the government. Although any direct reconciling action was rarely ever taken by the government, politicians were able to claim that they had done something about the complaints (Howden, 2017).

By 1906, lawmakers recognized the need for a legitimate body to handle complaints related to rail transportation and thus the ORMB was formed. Over time, as land use planning became more sophisticated and complex with the post-war boom and increase in population and 
development, the ORMB evolved to become the Ontario Municipal Board (OMB) and so its jurisdiction broadened considerably (Ontario Municipal Board Act, 1932). By 1932, the OMB was given powers to supervise the Bureau of Municipal Affairs (now Ministry of Municipal Affairs) in that one sitting member of the Board would be in charge of all municipal matters within the Province of Ontario. The member would be known as the Commissioner for Municipal Affairs for that year or term (Howden, 2017).

With the Planning Act of 1946, the Provincial Government had created the first planning framework in law for Ontario. Similar to today, municipalities were expected to implement Provincial Planning Policy, however the OMB was the final approval authority for all municipal zoning by-laws and official plans. According to Howden (2017) and Krushnelnicki (2007), the Minister of Municipal Affairs was technically responsible for approving or rejecting OPs and the subdivision of residential land but the Board could be called on, by referral, to overrule such decisions. Further amendments to the Planning Act elevated the Board's decision-making power on approvals of site plans, bonus zoning, interim control-bylaws, and temporary use by-laws (Krushelnicki, 2007). With every additional amendment, the OMB grew closer to the adjudicative body witnessed over the past decade or so. 
As the OMB grew in membership and power, so did the controversy surrounding the Board. With the enactment of the Planning Act, municipalities now had the authority to prepare planning documents and adopt planning controls like Official Plans and Zoning By-Laws. New developments within urban areas and suburbs conformed to these new policies, while older parts of Toronto were seen as outdated in light of these new policies. The redevelopment of different areas across the city led to anger amongst original residents who would challenges planning decisions by appealing to the OMB. Developers found themselves on the other side of the equation, needing to appeal to the OMB to overcome what many would deem to be NIMBYism. Both sides discovered how to make effective use of Ontario's land use planning appeal system to help them reach their goals (Krushelnicki, 2007).

The OMB of the 1980 s, 1990 s, and early 2000 s took the form of the government of the time. Upon the formation of Ontario's first New Democratic Party (NDP) government under Bob Rae, the Planning Act was comprehensively revised (Ontario Bill 163, 1995). It was revised once more by Mike Harris' Progressive Conservatives (PCs) immediately after (Ontario Bill 20, 1996). According to Krushelnicki (2007), the NDP and PC amendments revised many planning practices within the province of 
Ontario but did not significantly alter the authority of the OMB. One such example was the elimination of appeals to cabinet of OMB decisions by the PCs in the early 1980s. This change essentially made the Board the final arbiter of planning policy in Ontario. This change, however, was reversed once the Liberals took back power in 2004-2006 with the exception that cabinet could only review hearings in which the Province had declared an interest prior to the hearing (Ontario Bill 26, 2004-2006).

Throughout the 2000s and into the 2010s, the OMB garnered a reputation for being developer-friendly (Jackson, 2018). Many believed that the Board had too much power, that it could, and would, approve essentially any development no matter how ludicrous or inappropriate for the site. This resentment was particularly present amongst residents and lawmakers within the city of Toronto. At one point, the North York Community Council voted to name a city street "OMB Folly" after the Board had overruled its decision to reject an application for a 36-unit townhouse complex (Moloney, 2008). Additionally, Moore's (2013) research found that the majority of OMB decisions between 2000 and 2006 were in favour of developers, furthering the narrative that the appeals body was developer-friendly. That being said, nothing in Moore's (2013) research found that this didn't constitute good planning. Although 
the OMB was, for the majority of cases, ruling in favour of applications put forth by developers, those applications usually had supporting planning opinions from municipal planning staff (Moore, 2013). The OMB, though perceived to be favouring developers, was simply enforcing good planning policy as described in municipal official plans and the Growth Plan (Moore, 2013).

As a consequence of this developer-friendly narrative, in June 2016, the Ontario government finally launched a review of the scope and effectiveness of the OMB. The review stemmed from complaints claiming that the Board was unaccountable to the communities it was effectively planning, and that it would overwhelmingly rule in favour of developers (Pagliaro, 2017). Upon completion of the OMB review (2016b), the Province of Ontario passed Bill 139, the Building Better Communities and Conserving Watersheds Act, 2017 with the objective of creating a faster, more affordable, accessible, and transparent appeals process. Bill 139 replaced the OMB, as of April 3, 2018, with a new appeals body called the LPAT. 


\section{CHAPTER 5: COMPARATIVE ANALYSIS}

\section{Structural Context: The Attributes of the Planning System}

Before analysing the land use planning appeal systems and bodies of either Ontario and Oregon, it is important to review the planning systems in which they operate. While it is true that the land use appeals process can be slow, uncertain, and lead to a lack of supply, it can also be said that the planning systems themselves could be contributing to more appeals thus indirectly impacting supply and affordability.

\section{ONTARIO}

Ontario's land use planning system is generally regarded as a topdown system. The system follows a rigid land use planning hierarchy with the Province of Ontario issuing planning policy and the municipalities conforming to it. This is because municipalities are essentially "creatures of the province". Under the Canadian Constitution, provinces have exclusive control over cities and municipalities, hence the all-too-common phrase "municipalities are creatures of the Province." Furthermore, Tindal and Tindal (2004) identify two fundamental elements of the provincialmunicipal relationship: (1) "The incorporation (or creation) of municipalities is at the discretion of the provincial legislature, and does not require the consent of the people in the affected locality, and (2) The authority 
conferred on the municipal corporation is not local in nature but derives from the provincial government."

In Ontario, the Planning Act sets out the ground rules for land use planning in the province. The act seeks to promote sustainable economic development while balancing the interests of the natural environment, provides for a land use planning system led by provincial policy, and ensures a democratic land use planning and appeals process, among other key responsibilities. Additionally, the Province of Ontario is responsible for issuing the PPS under the Planning Act.

The PPS provides policy direction on matters of provincial interest related to land use planning and development. Naturally, the direction in which the PPS has historically directed policy has depended on the political party in power, as well as the land use planning challenges of the time. The most recent PPS was issued in 2014 and it, for instance, places an importance on building strong healthy communities, the wise management of resources, and protecting public health and safety. In the context of planning hierarchy, the Planning Act requires that any decisions or exercised authority that affects planning matters must be consistent with the PPS. 
The Ministry of Municipal Affairs and Housing (MMAH) is the ministry responsible for setting Ontario's land use planning rules and overseeing their implementation by municipalities. The Ontario Growth Secretariat is the policy group at the MMAH that is responsible for growth management policy in the Province. Through consultation with various stakeholders, these groups developed the province's Growth Plan in 2006 and consequently updated it in 2017 . The Growth Plan's guiding principles for the Greater Golden Horseshoe (GGH) are to: support the achievement of complete communities, prioritize intensification and higher densities, and support a range and mix of housing options. These principles are actualized through specific land use planning regulations, the most notable of which are that municipalities: must direct 60 per cent of all new growth within the urban boundary, and must ensure that any new growth outside of the urban boundary achieves a minimum density of 80 people and jobs per hectare (some municipalities have been granted until 2031 to achieve this target and are permitted to maintain at 60 people and jobs per hectare until then) (Province of Ontario, 2016b).

\section{OREGON}

Similar to Ontario, the state of Oregon's planning system is centralized (Walker and Hurley, 2011). As previously mentioned, the main 
reason that this research compares Ontario to Oregon is because the state is generally regarded a 'best practise' system across planning jurisdictions (Horne, 2014). Putters (2011) also notes that Oregon's planning system is possibly the best-known planning program, in North America, that integrates local, regional, and state planning efforts and initiatives.

Oregon was one of the first jurisdictions to use 'smart growth' planning policy and is one of the only two remaining first wave smart growth states today (Ingram et al., 2009). The current Oregon planning system was established in 1973 when the issue of growth management became a top priority for lawmakers in the state (Barnett, 2000). Backed by calls from the public to address rapid suburbanization, uncontrolled growth, over-extraction and over-use of natural resources, and traffic congestion, state mandated planning was seen as a viable solution (Sullivan and Clark, 2013). In 1973, the state of Oregon passed Bill 100, establishing the Land Conservation and Development Commission (LCDC) and the Oregon Department of Land Conservation and Development (DLCD) (Gieseler, Lewallen, and Sandefur, 2006). 
The mandate of the LCDC is to establish statewide planning goals which provide policy direction for land use planning in Oregon, as well as to oversee the operations of the DLCD (State of Oregon, n.d.). It is mandatory for every municipal comprehensive plan to conform to the state-level planning goals. Mualam (2014) states that while this is a topdown model, it is merged with bottom-up decision making which leaves municipalities a "wide margin of discretion" to manage and regulate their own affairs in accordance to the principles of "Home Rule" and "Police Power". These ideas are prevalent in American local governance and essentially are to "give municipalities greater control over their own affairs" and also "greater leeway to undertake various actions of their own without first having to obtain express state permission." (Caves, 2005). While municipalities play a vital role in controlling development, there is a high level of involvement at the state level when it comes to regulating land use thus making the planning system of Oregon comprehensive and top-down (Mualam, 2014). Mualam (2014) also highlights that the state of Oregon's Land Use Board of Appeals (LUBA), as a government-appointed body, is also a symbol of government's involvement in the planning system, and of its control over local development. The LUBA is a critical piece of the appeals puzzle and will be further analysed throughout this paper. 


\section{ANALYSIS}

As stated, both the state of Oregon and the province of Ontario have centralized planning systems. However, there is a distinction between the two jurisdictions which could be resulting in an excessive number of appeals within Ontario. Ontario, unlike Oregon, is very particular and specific about quantifying population and job growth which directly speaks to the nature of the relationship between province and municipality. As per the Growth Plan, the Province of Ontario not only provides general planning principles it desires to be implemented (intensification, complete communities, protection of natural heritage features, etc.), but also distributes future population expectations to municipalities. Essentially, municipalities do not have complete autonomy when it comes to how those principles are manifested into their own urban landscapes. Furthermore, in the past, the Growth Plan has received criticism for taking a one-size-fits-all approach in regard to density targets. When the latest version of the Growth Plan was initially released for public consultation, there was a swift response from the development industry and the public regarding the rather ambitious density targets the Province wanted to see in more suburban municipalities such as the city of Markham. The critiques centered on the fact that many of the municipalities that were expected to allocate $60 \%$ of all growth within their 
urban boundary, and in some cases allocate 200 residents and jobs per hectare within their 'downtowns', simply did not have the infrastructure necessary to accommodate that level of growth. To this end, the Growth Plan would not be achieving its desired goal of creating complete and healthy communities. Instead, the Growth Plan would be counter-intuitive as, according to the Province (2017), the efficient use of infrastructure is a key function of complete communities irrespective of whether they are urban, suburban, or rural.

Although Oregon's planning system is centralized, its Statewide Planning Goals are more general guiding principles than specific policy prescriptions such as the ones found in Ontario's Growth Plan. Each of the 19 Statewide Planning Goals come with a set of guidelines surrounding the goal's implementation, however, the State of Oregon itself deems them to be "suggestions" as they are not mandatory. An excerpt from a summary of Oregon's Statewide Planning Goals, specifically the goal related to housing, reads as follows:

HOUSING: This goal specifies that each city must plan for and accommodate needed housing types, such as multifamily and manufactured housing. It requires each city to inventory its buildable residential lands, project future needs for such lands, and plan and zone enough buildable land to meet those needs. It also prohibits local plans from discriminating against needed housing types. 
The planning goal related to housing is general to an extent that it can effectively require municipalities to plan for a diverse range of housing options, and still provide them with the freedom to decide how they wish to implement it. As such, municipalities are more able to plan for densities and housing types that best suit their current and future infrastructure capacities, and the market tastes of their consumers. Residents of any city in a jurisdiction would be less likely to appeal developments if the developments themselves were appropriate in terms of density and urban form. This would decrease the number of land use planning appeals which negatively impact housing affordability due to the cost the costs, in terms of both time and money, incurred by developers.

It is this balanced cohesion of municipal autonomy and planning centralization that Oregon's planning system is regarded a global bestpractice case study. The Province of Ontario could greatly benefit if it were to investigate reforming its planning model to something similar. A system that would set high-level planning principles, without prescribing one-sizefits-all density targets, or density targets at all for that matter, would allow municipalities to consult with their residents to lessen the number of appeals and thus increase housing affordability. 


\section{Overview and Adjudicative Methods}

The state of Oregon's appeals body is the Land Use Board of Appeals (LUBA). Before its creation in 1979, the LCDC was responsible for hearing land use appeals (State of Oregon, n.d.). The two main reasons for the LUBA's creation in 1979 were: (1) to implement State-wide planning goals, and (2) to replace the former ineffective appeal system (Sullivan, 2000). The previous appeal system had been considered "costly, cumbersome, and produced unpredictable outcomes and much confusion with respect to the interpretation of the State Planning Goals." (Mualam, 2014). The state of Oregon initially introduced LUBA as a fouryear experiment, intending to expedite decision making in accordance with sound principles of judicial review (Basham, 2010). When the State of Oregon decided to make the tribunal permanent, it created an agency of experts which produces accurate and consistent decisions related to land use planning (Sullivan, 2000).

The personnel composition of the LUBA consists of a panel of three members who possess legal training and are considered expert attorneys in land use planning law. Members of the LUBA's panel are also appointed by the Governor of Oregon. Traditionally, the practice of the 
LUBA is to have the entire panel hear each case; however, members may hear cases individually (State of Oregon, n.d.).

The LUBA mediates and adjudicates cases related to planning that arise from city council decisions and decisions made by central government. LUBA's mandate is to simplify the appeal process, expedite resolution of land use disputes, and provide consistent interpretation of state and local land use laws (State of Oregon, n.d.). In the state of Oregon, exclusive jurisdiction has been granted to LUBA over land use planning decisions, hence, LUBA also holds the authority to issue final orders on matters related to the Oregon's statewide planning goals (Sullivan, 2000).

The LUBA reviews planning decisions made by lower-hierarchy planning agencies such as municipalities. The LUBA can decide to either affirm a municipality's decision or order the municipality to review and rethink its original decision. Though the LUBA acts as a first-instance appeals body for the majority of cases, there are exceptions when it is a second-instance appeals body (Mualam, 2014). An example of this is when a decision of a professional agency, for instance regarding the heritage classification of a property, is appealed to a municipal council. 
The council's decision could then be appealed to the LUBA as a secondinstance appeals body (Mualam, 2014).

The LUBA adjudicates land use appeals through de novo hearings where the planning evidence is re-submitted for examination by the board. Additionally, the nature of LUBA hearings is adversarial meaning two opposing parties present their own versions of the facts and challenge the other party's version through methods like cross-examination (Hale, 2004).

As part of the Bill 139 reforms, cross-examination of expert witnesses is no longer permitted in LPAT hearings. From a transparency perspective, increased transparency in the appeals system being one of the goals of Bill 139, this is highly problematic. Expert evidence, without proper cross examination, is a problem partly because some witnesses who claim to be experts may not be experts at all (Barker, 2013). In Abingdon Meat Packers v. West Lincoln (Township) (1990), it was established that everyone can give evidence about something they know or about things they have seen but cannot give opinion evidence on matters in which they have no expertise. For example, a qualified engineer may give opinion evidence about engineering, but they may not give 
opinion evidence about planning or law because they are not qualified in those fields. While this is certainly helpful for ensuring that witnesses possess the qualifications for expert testimony, it does not provide any mechanism for analysing the expert's actual opinion based on facts. Historically, there have been many cases of witnesses claiming to have expertise because of their past experience and education, and then providing weak and indefensible testimony before a judge and/or jury. Without cross-examination, there is no way to determine the integrity and preparedness of an expert witness. There is no way to determine if an expert witness truly believes in their testimony and is prepared to defend it or is just interested being compensated for their time at a hearing.

In the public consultation document released by the Provincial Government in the fall of 2016, it was stated that Ontario's land use planning appeal system needed to be more transparent and inclusive. Allowing witnesses' opinions to be shielded from cross-examination is in no way conducive to transparency as they can testify without the fear of ramifications or reputational damage. As such, the Provincial Government should consider re-establishing adversarial de novo hearings, such as the ones the LUBA is involved with, to ensure transparency in Ontario's land use planning appeal system. 


\section{CHAPTER 5: FURTHER INVESTIGATION}

\section{Increase in Development Timelines}

Commentary from land development professionals and academics in the Greater Toronto and Hamilton Area would suggest that the time and resources required to get development approvals is already much too long (RCCAO, 2018). The Province of Ontario itself admits that the site plan approval process is slow which hurts the ability to get development through. In an attempt to address this, on April 20, 2017, the Province of Ontario established a Development Approvals Roundtable consisting of senior representatives from the province, GTHA municipalities, the development industry, and real estate sector. This roundtable was part of a larger 16-point plan to help more people find affordable homes, increase housing supply, protect buyers and renters, and bring stability to the real estate market (Orsini, 2017). The Development Approval Roundtable Action Plan (2017) made specific recommendations to the Ministry of Municipal Affairs to enhance engagement with municipalities to support the implementation of up-to-date zoning by-laws, develop a guidebook of

case studies and best practices that identify progressive zoning approaches, in addition to other recommendations related to environment 
and resources, infrastructure, and the role of innovation and technology in the planning process.

Lai et al. (2016) note that delays in obtaining development approvals have been advanced as a major reason for shortages and likely increases in the cost of housing. This inhibits a city's ability to attract creative, intelligent, and skilled talent to live and work in it (Toronto Region Board of Trade, 2018).

Bill 139 could exacerbate the issue of housing affordability in Toronto with some of the changes it brings to the land development and appeals process. Firstly, municipalities now have more time to make decisions with respect to official plans and zoning by-laws. Generally, the time limit to consider zoning by-law amendments has increased from 120 days to 150 days, and the time limit to consider official plan amendments has increased from 180 days to 210 days. The intended outcomes of these changes are: "(1) more time to asses planning matters and hear input from the public before making a decision, and (2) more time to negotiate solutions to possible issues and potentially avoid appeals at all." (Province of Ontario, n.d.) 
Although it is too soon to study what the effects of an additional 30 days is going to have on housing affordability in the region, we can infer that it is likely not going to be helpful. In a province where development timelines are already slow and drawn out, it can be said that any increase to the timeline would cost developers both time and money. The loss that developers incur because of longer timelines will most definitely be passed onto housing consumers in the form of more expensive housing. In a policy commentary published by the C.D. Howe Institute, Dachis and Thivierge (2018) concluded that delays on development approvals were one of the factors that were drastically increasing the price of housing by over $\$ 100,000$ in some Ontario municipalities. As such, the Province of Ontario should seriously consider and study whether the 30 day increase to review applications is alleviating or exacerbating Toronto's housing affordability crisis.

In addition to the initial addition of 30 days to review applications, Bill 139 further extends the development timeline by lessening's the LPAT's decision making power on the first appeal of an application. Prior to Bill 139, once the OMB heard an appeal, it would immediately be allowed to make a decision and conclude the matter. Appeals would essentially be filed with the municipality or approval authority and then be 
forwarded to the OMB for a de novo hearing and the Board would consider all the evidence independently. The Tribunal's authority is now limited in that it determines if the original decision made by a municipal council or approval authority is wrong or unreasonable based upon the tests of consistency with the PPS, conformity with Provincial Plans, and conformity with the Official Plan. Essentially, the general test of good land use planning no longer applies.

Furthermore, if the Tribunal does find in the appellant's favour, instead of making a decision and granting the appeal, it must relay the application back to the original decision-making body for a second review. Should the decision-making body fail to make a decision within a 90-day period, the matter gets sent back to the LPAT and the Tribunal then has broader powers to approve, modify, or refuse all or part of the plan.

To focus solely on timing aspect of the appeals system change, the new two-stage decision process adds at least an additional 90 days or three months to the approval process for developer without any guarantee of an approval being granted. Mayer and Tsuriel Somerville (2000) estimate that between 1985 and 1996, US metropolitan areas with more extensive regulation had up to 45 percent fewer housing starts and price 
elasticities that were more than 20 percent lower than those in lessregulated markets. More specifically, regulations that lengthened the development approval process, like Bill 139, had a greater impact on housing starts than service fees such as development charges.

\section{More Power for NIMBYs}

One of the central issues that the development industry and other critics of Bill 139 have had with the Act is the belief that OMB reform is going to result in NIMBYs (not-in-my-backyard) having more power and control against development in the province. NIMBYism refers to the protectionist sentiments and oppositional tactics adopted by community and ratepayer associations when faced with unwelcome development in their neighbourhood (Dear, 1992). Dear (1992) states that NIMBYism can have devastating effects on development which can be a barrier to increasing the municipal tax base. This not only negatively affects housing affordability, but the funding of municipal services as well since their delivery is dependent on municipal property taxes (Slack, 2002).

Bill 139 severely limits the decision making power of the LPAT. This change has the potential of seriously impacting development in the province of Ontario. Moore (2009) found that a city councillor's perception 
of the strength of neighbourhood opposition to development, or the ability of a neighbourhood association to affect the outcome of their re-election, could very well be a deciding factor in the councillor's decision regarding the development. Moore's (2009) analysis also reveals that as neighbourhood opposition grows, local politicians increasingly oppose developers. This turns a planning issue into a political issue. Granted, that the field of planning is highly political, it does not absolve local decision makers from enforcing good planning policy for the sake of furthering their political careers. The presence of the OMB also allowed politicians to offload the cost of decision-making to another body (Moore, 2009). Councillors were able to shield their true positions from public critique because in the end, the OMB would be ultimate decision maker and likely scapegoat for public anger.

The significant limitation of the LPAT's decision making power is not going to stop councillors from appeasing NIMBYs in their ward. However, the difference now is that there is limited access to a body to gauge and decide whether councillors' decisions align with official plan policies. City councillors have significantly less ability to "pass the buck" as Moore (2009) would say. They can reject development after development 
knowing it could buy favour with some of their more organized constituents and help their re-election chances.

This change may have significant impacts on housing affordability across the province of Ontario. There is already more than enough evidence that illustrates the significant long term impacts a lack of housing supply can have on affordability (Hilber and Vermeulen, 2010; Fingleton, 2008; Glaser and Gyourko, 2005). A further tightening of housing supply will undoubtedly decrease affordability and will leave the province of

Ontario is a less competitive position on a global scale. As such, the Province of Ontario should immediately re-open the land use appeals debate and consider the long-term consequences of lessening the LPAT's authority.

\section{Implementation Issues}

While the purpose of this major research paper is to recommend policy changes, it is important to analyse the implementation of Bill 139 as it stands now. This is because while the Province considers amending the Building Better Communities and Conserving Watersheds Act, there is still a massive LPAT backlog of over 30,000 homes (just in Toronto) present and new appeals are continuing to be filed (Landau, 2019). 
As with any change in policy, issues with implementation are almost certain (McLaughlin, 1987). The implementation of a policy also plays an important role in ensuring the delivery of the expected outcomes (Smith, 1973). In terms of Bill 139, the issues surrounding implementation are already being brought to light through professional commentary and staff reports from different municipalities in the province.

One of the issues surrounding Bill 139's implementation is the financial toll municipalities will have to pay. In an April, 2018 City of Toronto Staff Report regarding the implementation of Bill 139, the City Clerk, Chief Planner, and City Solicitor stated the need for additional staff resources in order to meet all of the obligations set out by the reforms. Specifically, the City Clerk's Office, Legal Services, and City Planning, requested 14 new staff resources including planners, lawyers, and registrars to manage an increased volume of appeals under the old system, commencement of appeals under the new system, the increased involvement in the review process by legal staff, increases in overtime, and several other sets of increased duties and responsibilities. Furthermore, the report recommended making several temporary staff positions permanent, likely expecting the implementation process around OMB reform to be cumbersome and require more attention. While this 
paper does not investigate the financial impacts of Bill 139 on every Ontario municipality, it is entirely possible that these same resource shortages are present across towns and cities outside of the city of Toronto. To ensure the smooth implementation of Bill 139, the Province of Ontario should provide municipalities with the funds they need to implement Provincial OMB reform. Municipal planning departments in the province of Ontario are already overworked (CBC News, 2016) and will not be able to implement Bill 139, in addition to conducting their regular planning duties, without additional resources. Since planning departments require additional resources as a direct result of Provincial interference, it is more than fair for them to request additional funds from the Provincial Government.

Another concern that many in the city building community have voiced about Bill 139 is about the new joint test. Specifically, how a municipal planning department would prove that their council's decision conformed to the Growth Plan and was consistent with the PPS. Squires (2017) states that limiting planning appeals based on a lack of conformity/consistency to Provincial Plans, the PPS, and Official Plans provides for an "uncertain test since Provincial policies are purposefully broad and some municipal and regional official plans do not provide levels 
of specificity needed, suggesting the determination of a municipal decision's consistency with such plans may be too easy and/or restrictive." 


\section{CHAPTER 6: FINAL DISCUSSION AND RECOMMENDATIONS}

Upon analyzing the potential impacts of Ontario's centralized planning system, and the Bill 139 reforms, it is clear that further reform is needed to improve the state of housing affordability in the province of Ontario. Moore's (2009) research clearly indicates that while the OMB was siding with developers, it was doing so in the instances where their applications had staff support. In light of this evidence, the basis for Bill 139 should be considered faulty and uninformed. The OMB was simply implementing Provincial Policies and Provincial Plans that were crafted by the Liberal Government. This same Liberal Government was criticizing the OMB while they loved to receive recognition for their forward thinking land use policies promoting intensification and containing urban sprawl. The irony is that the only way that these policies could be implemented was by means of the OMB.

Ontario's land use appeals system played a vital role in ensuring that an adequate amount of housing stock got to market. Now that the appeals process has become even more complicated, it is likely to exacerbate the region's housing crisis. As such, this paper lists five recommendations for land use planning and appeals reform that can get more housing stock to 
market, limit the number of appeals, increase transparency of the appeal process, and most importantly, improve the status of housing affordability in the province of Ontario. The recommendations are as follows:

1) Reform Ontario's Land Use Planning System to allow municipalities more control over the type of development that occurs within their borders.

Specifically, consider removing quantifiable density targets from the Growth Plan and shift policy to more general guidelines like Oregon's State Planning Goals, or set out different density targets for different municipalities depending on their level of infrastructure capacity and development pressure.

2) Return LPAT hearings to a de novo form that fits within an adversarial system.

Without the ability to cross-examine expert witnesses, there is no way in challenging their evidence or integrity in the testimony they provide. An adversarial system would allow for more transparency which was one of the goals of Bill 139. 
3) Allow the LPAT to make consequential decisions on land use planning matters in cases where councils reject an application.

There is evidence to suggest that local politicians' feelings towards a development can be influenced by their constituents despite of what the planning policy says. Without a consequential appeals body, there is a risk of local politicians caving to NIMBYs which could significantly impact housing supply and affordability in the province of Ontario.

4) Reduce the time allowed for municipalities to review a decision.

The province already struggles with a slow development process and to extend that even further is likely to negatively impact developers' ability to make a profit. These costs are likely to be passed onto the consumer which will only exacerbate the housing affordability crisis that the region is facing.

5) Immediately provide financial assistance to all municipalities in the province for the successful implementation of Bill 139 while discussions around policy change take place.

Municipalities are in dire need of resources and without them, Bill 139 will take longer to implement and staff will have less time for their regular day-to-day planning duties. 


\section{REFERENCES}

Barker, I. (2013). The dangerous art of cross-examination. Retrieved from http://www5.austlii.edu.au/au/journals/NSWBarAssocNews/2013/84 .pdf

Barnett, E. D. (2000) When Worlds Collide: The Convergence of the Land Use Planning Systems of the Netherlands and the State of Oregon. Available at http://www-sre.wu-wien.ac.at/neurus/Barnett.pdf

Basham, T. A., Board Member, LUBA. (2010). Oregon Land Use Board of Appeal (LUBA).

Bench, M. E., Dyke, G., \& Engell, B. (2018). Bill 139 - The Impact on Council and Councillors. Retrieved from https://www.amo.on.ca/AMOPDFs/Events/18/Presentations/Tuesday/LPAT_GG3_9amTues.asp $\mathrm{X}$

Canadian Mortgage and Housing Corporation. (2018). Examining Escalating House Prices in Large Canadian Metropolitan Centres (Rep.). Retrieved https://www.straight.com/files/v3/files/cmhc_housing_study.pdf

Caves, R. W., Editor. (2005). Encyclopedia of the City. New York, NY: Routledge.

Gieseler, S. G., Lewallen, L. M., \& Sandefur, T. (2006). MEASURE 37: PAYING PEOPLE FOR WHAT WE TAKE. Environmental Law,36(1). Retrieved from https://www.jstor.org/stable/43267246?seq=1\#page_scan_tab_cont ents

CBC News. (2016, November 17). Toronto city planners are 'drowning in work': Union report. Retrieved from https://www.cbc.ca/news/canada/toronto/city-planners-overworked1.3854997 
City of Toronto. (2018, April 27). Bill 139 - Amendments to the Planning Act and the Province's Land Use Planning Appeal System Implementation. Retrieved from https://www.toronto.ca/legdocs/mmis/2018/pg/bgrd/backgroundfile114749.pdf

Davies Howe. (2018). BILL 139 CHANGES TO PLANNING IN ONTARIO NOW IN EFFECT. Retrieved from http://www.davieshowe.com/omb-reform/

Dear, M. (1992). Understanding and Overcoming the NIMBY Syndrome. Journal of the American Planning Association,58. Retrieved from https://www.tandfonline.com/doi/abs/10.1080/01944369208975808

Fedio, C. (2011, June 29). OMB approves 10,000-unit plan for Downsview lands. Retrieved from https://www.thestar.com/news/gta/2011/06/29/omb_approves_1000 Ounit_plan_for_downsview_lands.html

Fingleton, B. (2008). Housing Supply, Housing Demand, and Affordability. Urban Studies,45(8). Retrieved from https://journals.sagepub.com/doi/abs/10.1177/0042098008091490

Glaeser, E. L. and Gyourko, J. E. (2003). The Impact of Building Restrictions on Housing Affordability. Economic Policy Review, Vol. 9, No. 2. Available at SSRN: https://ssrn.com/abstract=790487

Hale, S. B. (2004). The Discourse of Court Interpreting: Discourse Practices of the Law, the Witness, and the Interpreter. John Benjamins Publishing.

Hilber, C. A. L. and Vermeulen, W. (2010) The impacts of restricting housing supply on house prices and affordability: final report. Department for Communities and Local Government, London, UK. ISBN 9781409826248

Horne, A. (2014). Urban Growth Management Best Practices: Towards Implications for the Developing World. International Planning Studies. Retrieved from https://doi.org/10.1080/13563475.2014.942513 
Howard, J. W., Jr. (1969). Adjudication Considered as a Process of Conflict Resolution: A Variation on Separation of Powers. J. Pub. L., 18 (339).

Howden, P. H. (2017). The Ontario Municipal Board: The Last Trip. Victoria, BC: FriesenPress.

Ingram, G. K., Carbonell, A., Hong, Y., \& Flint, A. (2009). Smart Growth Policies: An Evaluation of Programs and Outcomes(Rep.). Retrieved https://www.farmlandinfo.org/sites/default/files/lincoln_smart_growt h_policies_an_evaluation_of_programs_and_outcomes_1.pdf

Jackson, A. (2018, April 6). The OMB is now officially gone. Retrieved from https://www.waterloochronicle.ca/news-story/8377906-theomb-is-now-officially-gone/

Krushelnicki, B. (2007). A Practical Guide to the Ontario Municipal Board (2nd ed.). LexisNexis Canada.

Kumar, S. (2005). Urban Design Decision-Making: A Study of Ontario Municipal Board Decisions in Toronto. Canadian Journal of Urban Research, 14 (2).

Landau, J. (2019, February 12). Deputy Mayor Bailão Calls for Action to Clear LPAT Backlog. Retrieved from http://urbantoronto.ca/news/2019/02/deputy-mayor-bailão-callsaction-clear-Ipat-backlog

Map Your Property. (2019, January 15). Experts Weigh in on the Local Planning Appeal Tribunal 1 Year Later. Retrieved from https://medium.com/@mapyourproperty/experts-weigh-in-on-thelocal-planning-appeal-tribunal-1-year-later-81a7ee87b390

Mayer, C. J., \& Tsuriel Somerville, C. (2000). Land use regulation and new construction. Regional Science and Urban Economics,30(6). Retrieved from https://www.sciencedirect.com/science/article/pii/S0166046200000 $557 \#$ ! 
McLaughlin, M. W. (1987). Learning From Experience: Lessons From Policy Implementation. Educational Evaluation and Policy Analysis, 9(2), 171-178. https://doi.org/10.3102/01623737009002171

Moloney, P. (2008, October 8). It's street revenge on developer. Retrieved from

https://www.thestar.com/news/gta/2008/10/08/its_street_revenge_o n_developer.html

Moore, A. (2009). Passing the Buck: The Ontario Municipal Board and Local Politicians in Toronto, 2000-2006(Rep.). Retrieved from https://www.cpsa-acsp.ca/papers-2009/Moore.pdf

Mualam, N. (2014). Appeal Tribunals in Land Use Planning: Look-Alikes or Different Species? The Urban Lawyer,46(1). Retrieved from https://www.researchgate.net/publication/287816384

Ontario Bill 20, 1996.

Ontario Bill 26, 2004-2006.

Ontario Bill 163, 1995.

Ontario Municipal Board Act, 1932.

Orsini, S. (2017, November). DEVELOPMENT APPROVAL ROUNDTABLE ACTION PLAN (Report). Retrieved http://www.mah.gov.on.ca/AssetFactory.aspx?vid=25577

Province of Ontario. (n.d.). Bill 139 Information Session Presentation. Retrieved from https://www.perthcounty.ca/en/countygovernment/resources/files/18-03_MMA_Presentation_Bill-139.pdf

Province of Ontario. (2016a). Building Complete Communities: Supporting Quality of Life. Retrieved from http://www.mah.gov.on.ca/AssetFactory.aspx?did=15007

Province of Ontario. (2016b, October). Review of the Ontario Municipal Board: Public Consultation Document. Retrieved from http://www.mah.gov.on.ca/AssetFactory.aspx?did=15814 
Putters, B. (2010). The Special Case of Oregon: The Heated Debates Regarding Measures 37 and 49. In Takings International: $A$ Comparative Perspective on Land Use Regulations and Compensation Rights. American Bar Association.

Residential and Civil Construction Alliance of Ontario. (2018). The GTHA's Unbalanced Housing Stock: Benchmarking Ontario's New LPAT System (Rep.). Retrieved from http://www.rccao.com/research/files/RCCAO_LPAT_REPORT_201 8.pdf

Salsich, P. W., Jr., \& Trynieki, T. J. (2003). Land Use Regulation: A Legal Analysis and Practical Application of Land Use Law.

Slack, E. (2002, February). Municipal Finance and the Pattern of Urban Growth. Retrieved from http://www.urbancentre.utoronto.ca/pdfs/elibrary/Slack_MunFinance-Urb-Growt.pdf

Smith, T. B. (1973). The policy implementation process. Policy Sciences,4(2). Retrieved from https://link.springer.com/article/10.1007/BF01405732

Squires, I. (2017, July 5). Bill 139: A new planning regime is on the horizon. Retrieved from http://www.urbanstrategies.com/news/bill139-new-planning-regime-horizon/

State of Oregon. (n.d.). Frequently Asked Questions (FAQ's). Retrieved from https://www.oregon.gov/luba/pages/faq.aspx

State of Oregon. (n.d.). Land Use Board of Appeals - About Us. Retrieved from https://www.oregon.gov/LUBA/Pages/about_us.aspx

Sullivan, E. J., \& Clark, B. (2013). A Timely, Orderly, and Efficient Arrangement of Public Facilities and Services - The Oregon Approach. Williamette Law Review,49(411). Retrieved from https://papers.ssrn.com/sol3/papers.cfm?abstract_id=2288085 
Sullivan, E. J. (2000). Reviewing the Reviewer: The Impact of the Land Use Board of Appeals on the Oregon Land Use Program, 19791999. Retrieved from https://heinonline.org/HOL/LandingPage?handle=hein.journals/willr $36 \div=23 \& \mathrm{id}=\&$ page $=$

The Ontario Railway and Municipal Board Act, 1906.

Toronto Region Board of Trade. (2018). BETTER HOUSING POLICY PLAYBOOK 2018 MUNICIPAL ELECTION. Retrieved from https://www.bot.com/Portals/0/BOARD_AFG_Municipal01_housing _playbook_FINAL.pdf

Walker, P. A., \& Hurley, P. T. (2011). Planning Paradise: Politics and Visioning of Land Use in Oregon (Society, Environment, and Place). Tuscon, AZ: University of Arizona Press.

WoodBull LLP. (2017, December 18). Bill 139 - Comparison Tables: Planning Act Amendments; OMB Act \& LPAT Act. Retrieved from http://www.woodbull.ca/resources/wood-bull-blog/2017/12/18/bill139---comparison-tables-planning-act-amendments-omb-act-Ipatact 